THE MYTH OF AMERICAN DIPLOMACY 



\title{
THE MYTH OF
}
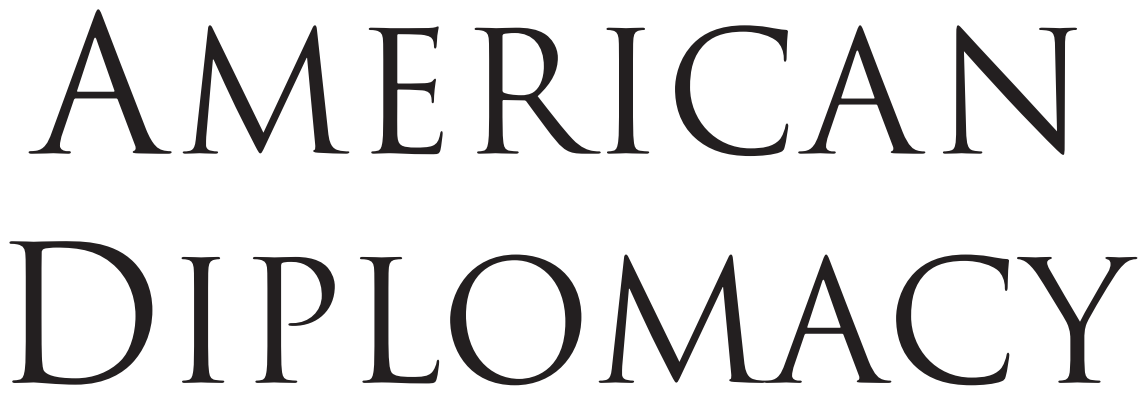

National Identity and

\section{U.S. Foreign Policy}

\author{
Walter L. Hixson
}


Copyright $\odot 2008$ by Walter L. Hixson.

All rights reserved.

This book may not be reproduced, in whole or in part, including illustrations, in any form

(beyond that copying permitted by Sections 107 and 108 of the U.S. Copyright Law and except by reviewers for the public press), without written permission from the publishers.

Designed by James J. Johnson and set in Minion Roman by The Composing Room of Michigan, Inc. Printed in the United States of America by Sheridan Books, Inc., Ann Arbor, Michigan.

\section{Library of Congress Cataloging-in-Publication Data}

Hixson, Walter L.

The myth of American diplomacy; national identity and U.S. foreign policy / Walter L. Hixson.

p. $\mathrm{cm}$.

Includes bibliographical references and index.

ISBN 0-300-11912-7 (alk. paper)

1. United States-Foreign relations. 2. Nationalism-United States-History. 3. National characteristics, American. 4. United States-Foreign relations-Historiography. 5. United States-Foreign relations_-Philosophy. 6. United States-Military policy. 7. MilitarismUnited States-History. I. Title.

$$
\begin{array}{rc}
\text { E183.7.H595 } & 2008 \\
327.73 \text {-dc22 } & 2007031173
\end{array}
$$

A catalogue record for this book is available from the British Library.

The paper in this book meets the guidelines for permanence and durability of the

Committee on Production Guidelines for Book Longevity of the Council on

Library Resources. 
That is the true myth of America. She starts old, old, wrinkled and writhing in an old skin. And there is a gradual sloughing off of the old skin, towards a new youth. It is the myth of America.

-D. H. LAWRENCE 
